\title{
From Fairy Tale Narratives to Their Animated Versions
}

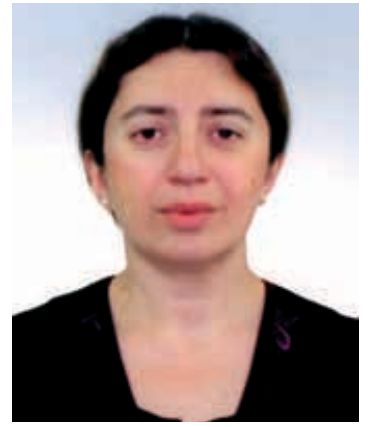

Alvard Jivanyan

Colk tale rhetoric and poetics are both notorious for their $\boldsymbol{H}$ rigidity and conservatism. A completely new and fascinating potential of fairy tale poetics and rhetoric opens when we consider them in the animated versions of fairy tales.

In terms of its relation to the linear tale, the poetics of the animated film is unique. It should be mentioned that despite the more mobile and flexible character of animation, most creators of animated tales prefer not to abandon the poetics of the linear narrative, which is inimitable. What is more, animators tend to lean heavily upon it; most versions begin and end with opening and closing formulas identical or at least similar to those found in most traditional or classic fairy tales. Once upon a time seems to be irreplaceable.

Many animated versions of fairy tales start showing a beautifully bound book and as it slowly and heavily opens, the story unfolds. The story teller, either visible or unseen, is introduced as an important character. The placing of a fairy tale book at the opening of a cartoon film can be regarded as a kind of animation device successfully bridging the divide between the cartoon version and the classic narrative. This device is rather widely used. For some reason the spell of the linear text still remains unsurpassed and the charm of the animated film fails to equal the spell of the linear text. Linearity suggests order succession in time and space which we will not give up readily. Evidently the transition from the linear text to the cartoon film is an intricate process. Walt Disney, too, used the outlines of a story book in his works. However, in many cases it was rather a fleeting allusion. Pinocchio (Disney, 1940), for example, opens showing a heavy leather tome with two locks on the leather cover. Once open, it is reminiscent of a box of beautiful images rather than a volume of wonder tales as it is textless.

A unique place in this respect belongs to Don Bluth's Thumbelina (1994). In this film a book plays a major role. To be more exact, it plays two roles; one is the traditional role of opening the story, which is present in a great number of fairy tale films. The other is that the book becomes part of the setting in which characters perform their actions. Thumbelina learns about the Prince of Elves from a book her mother reads to her in the evenings, a fairy tale book, one might think, for it seems the only appropriate kind of literature to be read by fairy tale characters. As the tiny heroine paces up and down the page of the book, she manages to make out the figure of the Prince. And as she dreamily measures the page space with her steps, it seems that she wants to become a character in the book story, to be part of it. This beautiful film is designed in such a way that the 
narrative spaces of the story book and the film are mutually penetrable. Don Bluth is enchanted by the simple cham of the book narrative. Now and then he alludes to it, interrupting the breathless pace of the animated story.

In other words, we can say that we see an intermittence of linear and visual performance. Thus, in certain cartoon films the description of events is distributed between linear text and animation. between writer/teller and motion. Often the teller is presented metonymically through a writing hand or a belind-the-screen voice. Film makers are sometimes poor story tellers. It is probably for this very reason that they put into the film the figure of a story te]ler to make the performance authentic and reliable. The teller is either visible or unseen, an old-fashioned mysterious voice, and becomes one of the characters in the story. One of the best examples is the Soviet version of the Steadfast Tin Soldier, after Andersen's tale. The writer cannot be seen, we behold only his hands, one of them holding a pen which he puls down from time to time to ponder the exciting or sorrowful events of the tale. The hands indulge an active gesticulation, revealing how deeply the author is concerned with the fate of his characters.

Frequently, the poetics of the tale is nevertheless modified, being distorted for the sake of simplicity and to fit the hectic pace of certain motion films. The list of such films could be long, but sometimes the fairy tale poetics and rhetoric are abandoned by great animators. As an example we may cite one of Walt Disney's best works, Snow White and the Seven Dworfs (1937). It completely lacks the opening part of Grimms' tale.

Once upon a time there lived a lovely little princess named Snow White. Her vain and wicked Stepmother the Queen feared that some day Snow White's beant' w'ould smpass her own. So she dressed the little princess in rags and forced to work as Scullery Maid.

Cutting off the opening part not only deprives the film story of the beautifis winter scene but also deprives the protagonist's name of its motivation, so importimi for the development of the whole narrative. In Disney's version of the tale the appearance of the main character is ummotivated and lacks the necessary retardation so important for the text. The removal of the opening part also reduces the number of the characters in the tale by taking out the figure of Snow White's natural mother, who gives the tale its moody and solemn disposition. It is important to mention that the fairy tale narrative is already brief. It may be said to be a "sieved" narrative and eannot be sifted further. This rules out the usual skipping of text lines while reading classical narratives, which is described by Roland Barthes in Pleasure of the Text: "...we do not read everylling with the same intensity of reading; a rhythm is established, casual, unconcerned with the integrity of the lext: our very avidity for knowledge impels us to skim or to skip certain passages (anticipated as "boring") in order to get more quickly to the warmer parts of the anecdote ... we boldly skip (no one is watching) descriptions, explanations, analyses, conversations..." (Barthes 2000, 11).

This aspect of Disney's work has been criticizwd by Jack Zipes: "For Disney, the Grimms' tale is not a vehicle to explore the deeper implications of the narrative and its history. Rather it is a vehicle to display what he can do as an animator with the latest technological and artistic developments in the industry. The story is secondary... In 
Disney's early work with fairy tales in Kansas city. he had a wry and irreverent attitude toward the classical narratives..," (Zipes 1994, 93).

And further: "Disney's adaptation of the literaly fairy tale for the screen led to a number of changes in the institution of the genre. Technique now takes precedence over the story, and the story is used to celebrate the technician and his means...The images and sequences engender a sense of wholeness, seamless totality, and hamony that is orchestrated by a savior/technician on and off the screen. Though the characters are fleshed out to become more realistic, they are also one-dimensional and are to serve functions in the film. There is no character development because the characters are stereotypes, arranged according to a credo of domestication of the imagination". (Zipes 1994, 94)

In fact, abridgement of the narrative is almost a regular feature of cartoon films, for impetuousness is an essential feature of animation: "Simplicity was one of the keys to a successful cartoon feature and, as Disney learned. one of the most difficult things to achieve. Relying on a classic story like Snow White was both an advantage and a problem" (Mattin 1987, 53).

On the one hand, simplicity is a feature which animation may have inherited from the fairy tale genre. Vladimir Propp, among others, has highlighted the unique textual minimalism of the fairy tale narrative (Propp 2001). Following Propp, Umberto Ecco in his Six Walks in the Fictional Woods writes: "Any narrative relating of imaginary events should inevitably and fatally be swift, for in creating a world involving myriads of events and personages it is impossible to tell everything about that world."

However, Disney's version of Snow White does achieve simplicity and dynamic pace to the detriment of the poetics of the original text. Jack Zipes quotes Richard Schickel, who observes: Disney "could make something his own all right, but that process nearly always robbed the work at hand of its uniqueness, of its soul, if you will. In its place he put jokes and songs and fright effects, but he always seemed to diminish what he touched. He always came as a conqueror, never a servant. It is a trail, as many $h$ a ve observed, that many Americans share when they venture into foreign lands hoping to do good but equipped only with know-how instead of sympathy and respect for alien traditions" (Zipes 1994, 93).

A comparable technique of simplification is regularly applied in adapted retellings of classic fairy tales. Thus, for instance, a number of versions of Little Red Riding Hood begin wishout explaining the origin of the metonymic name, and it appears in the narrative unmotivated. As a result. the logic of the narrative is violated: the opening of the tale is abrupt. Analogous narratives suggest that the hearer or the reader should know the original text. No wonder similar editions are heavy on illustrations, which turn to be more important than the scanty text. Very often the narrator is the illustrator, so that the text is secondary to picture.

When the linear narrative is transformed into its animated adaptation, its thetoric vanishes through a sequence of modifications. Owing to the unique possibilities of animation, tropes in cartoon versions of fairy tales obtain peculiarities which are unthinkable in the case of the Iinear narrative. The motion picture has technical potential to realize a number of tropes concurrently, whereas the linear narrative camnot 
accomplish such a task. We shall examine and interpret this peculiarity on the example of a number of snow tropes used either as similes or metaphors. Significantly, it is difficult to discriminate between these two tropes in cartoon films, so that it is easy to agree with scholars who see the difference between simile and metaphor as consisting merely in the use of the comparative particle as or like. When transferred from the verbal to the visual plane, the difference is neutralized. A similar observation results from examining fairy tale illustrations involving an episode of the tale containing a simile. The visual image does not tell similes from metaphors. And no wonder, for both illustration and animation submit the narrative trope to the procedure of visualization. The demarcation of the two seems to be relevant in the case of verbal art only.

Below we will consider the opening part of the Russian cartoon film Snegourochka (The Dictionary of Russia translates it as Snow Maiden). The filn was created in 1952 at Sovtzmultfilm studio by a master animator. Ivanov-Vano.

Snegourochka opens with a beautiful winter landscape. The snow flakes scarcely touch the frosted earth. Snow in this opening scene is included, almost simultaneously, in four different metaphoric relations.

- Snow flakes revolving in the icy winter air bring to mind tiny candles with golden wicks and golden flames, which twinkle and flicker incessantly against the low hanging sky. The association is fortified by the presence of a milk-white moon in the low banging sky.

- A further metaphoric relation is established between snow flakes and stars, myriads of silvery stars, almost identical to snow flakes, but still distinguishable from them: unlike snow flakes. they are completely motionless. Here is the tropc in action, a visual simile/metaphor which the less powerful pen would possibly describe as follows: the snow flakes are golden candles dancing in the firost.

- Yel a third relation reveals itself: as the film progresses, a little flight of birds appears against the pale disc of the moon and their falling feathers easily metamorphose into show flakes.

- A fourth corretation can be traced as Spring arrives in her beautiful chariol and spreads tiny flowers onto the snow-covered soil. The minute blossoms readily bring to mind the snow flakes.

No doubt the linear trope would not wield the brightness and the power of its cartoon counterpart. A final, additional impact is added to the cartoon narrative with the help of Rimsky Korsakov's powerful music. It is owing to this final touch that the setting of the story becomes more and more tense, even disturbing, and we are prepared for the inescapable appearance of a non-human character, Leshy, the master of the forest.

It should be mentioned that parallels between snow and feathers are not known from animation only. Some of them are present in the folk thetoric of many cultures. In Holstein, Germany, when it snowed people would say: "St. Peter is airing his bed" or "the angels are pulling out their feathers". Similarly, in Hessen when it was snowing people said, "Mother Hulda is shaking her bed". Moreover, folk beliefs suggesting affinity between snow and feathers are often found in fairy tales. This last folk belief was reflected in the famous tale of the Brothers Grimn, Mother Hulda: 
What are you afraid of. my dear child"' Come and live with me, and if you to the house-work well and orderly, things shall go well with you. You must take great pains to make my bed well and shake it up thoroughly, so that the feathers f7y, and then in the world it snows, for I am Mother Hulda. (Brothers Grimm 1993,207)

Upon closer reading, the associative link between the character of Mother Hulda and snow is doubled. As a patron of spinners, Mother Hulda, also known as Mother Holda and Mother Holle, inevitably has to do with wool and cotton, which in their turn often stand as metaphors for snow, or the reverse: snow figures as a metaphor for wool or cotton.

Another tale recorded by the Brothers Grimm - The Snow White and the Seven Dwarfs opens with a quiet and beautiful winter scene including a parallel between snow and feathers:

It was the middle of winter, and the snow flakes were falling like feathers from the sky: a queen sat at her window' working, and her embroidery-frame was of ebony:

(Brothers Grimm 1993, 214)

The description of the winter landscape in Hans Christian Andersen's Snow' Queen seems to be more remotely related to similar beliefs. Here similarity between snow and feathers is made more vivid and even hyperbolized:

The snow' flakes grew bigger and bigger till at last they looked like big chickens. All at once they sprang on one side, the big sledge stopped and the person who drove got up, coat and cap smothered in snow. It was a tall and upright lady all shining white, the Sinow Queen herself. (Andersen 1993, 188)

Images of snow appear recurrently in fairy tale narratives, now as a snow belief (snow flakes are feathers of Mother Hulda's bed), now as a snow trope (snow flakes fell down like feathers). The interconnection of the two is beyond doubl and it is difficult to claim that one of them might have generated the other. To put forward such a question is tempting, though pointless. One thing is certain: the archaic trope stands far closer to the folk belief than the poetic trope (if we choose to keep to such a differentiation), and they should not be always equated. A poetic trope is a challenge to look at the world in a new way or even to open up a new possible world. The archaic trope is an echo of a past, forgotten world. In the poetics of the folk and fairy tale the snow is always white. In poetry, however, it may change color. The following is an extract from Ted Hughes's poem Febriary:

The wolf with its belly stitched full of big pebbles;

Nibelung wolves barbed like black pine forest

Against red sky: over blue snow: (Hughes 2003, 44)

Any fairy tale is to a certain degree theatrical. and this quality is transferred and carefully preserved in animated films based on fairy tales, at least in Russian post-war motion films. What makes Russian cartoon films of the fifties definitely dissimilar to 
Disney's work, for instance, is a distinct feeling of theatricality. All the actions are makebelieve. What is more, the setting in these films is deliberately fashioned so that it brings to mind the properties of a stage set. at a remove. In The Twelve Months (Ivanov-Vano, 1956), the narrative opens with a beautiful winter scene: the forest with its strong, lofty trees is shown from different angles, and the camera turns what seems to be a dense old wood round and round as if it were placed on a rotating stage. In a certain sense, the tall trees seem to take on the function of some strange, unique stage curtains, which move aside as the story unfolds to reveal the characters in it.

A comparable animation device is used in another of Ivanov-Vano's works based on a folk tale, In a Certain Kingdom (195...). The film opens with the view of the house of the main character, Yemelya. Though small, poor and almost bent under the weight of snow, this modest dwelling is placed on top of a hill. The cottage has to be there because it is to be watched, observed by us, the spectators. The effect recurs in the finale of the film. Yemelya and the Princess stand on the stove-top in an embrace. The stove glides smoothly over the white snow, more like some piece of stage equipment than a real stove. A crowd of peasants greet them heartily, but they are placed lower, at a distance from the embracing couple, obviously representing observers or spectators, while their costumes are more mundane and less colourful than those of the newly-weds. They express their admiration and excitement at the wonderful events by cries of joy and surprise and throw their caps into the air just as spectators of folk performances in Russia would. The film closes, as it opened, with a winter scene: heavy brilliant snow flakes fall upon the earth (it is not by chance that the terms close and open fit the fairy tale more than any other narrative genre).

Thus it can be argued that animated fairy tales are unique versions of classic narratives. The passage from the linear narrative to the non-linear cartoon film subjects the narrative to a number of modifications which are motivated by the peculiarities of animation.

\section{References:}

1. Andersen, Hans Christian. Fairy Tales, Wordsworth Children's Classics, 1993.

2. Barthes, Roland. Pleasure of the Text. New York, Hill and Wang, 2000.

3. Ecco, Umberto. Six Walks in the Fictional Woods (Russian tr.). St. Petersburg, Symposium, 2002.

4. Grimm, Jacob and Wilhelm. Grimm's Fairy Tales. Penguin Books, 1996.

5. Hughes, Ted. Collected Poems. Farrar, Straus and Giroux, 2003.

6. Kabakchi, V. The Dictionary of Russia. St.Petersburg, 2002.

7. Maltin, Leonard. Of Mice and Magic: A History of American Cartoons. Plume, 1987.

8. Propp, Vladimir. Morphology of the Folk Tale. Texas University Press, 2001.

9. Zipes Jack. Fairy Tale as Myth: Myth as Fairy Tale. The University Press of Kentucky, 1994. 


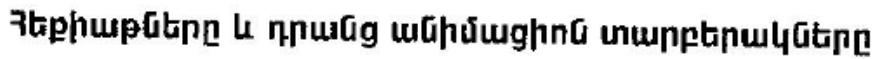

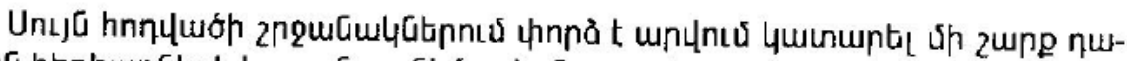

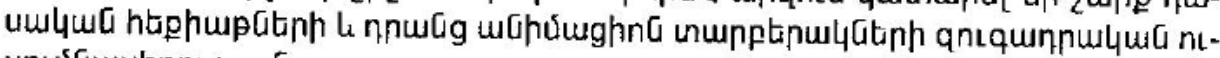
untúumupnnıp!ntâ:

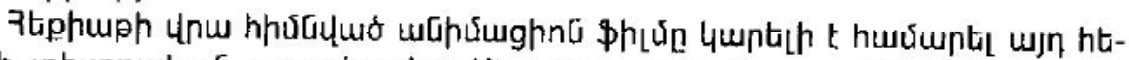

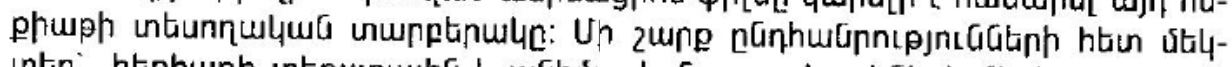

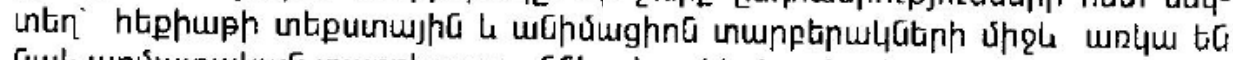

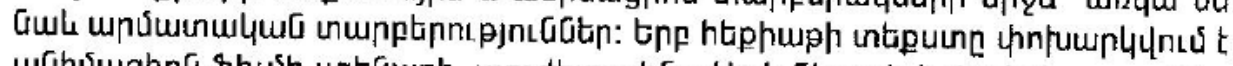

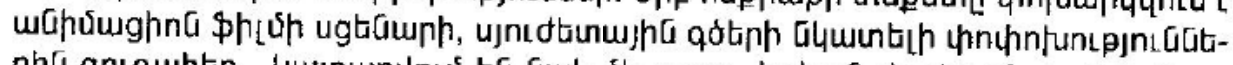

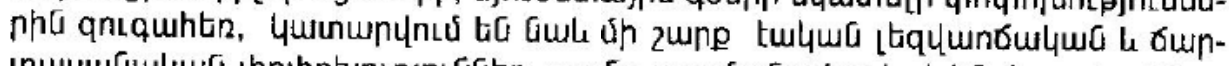

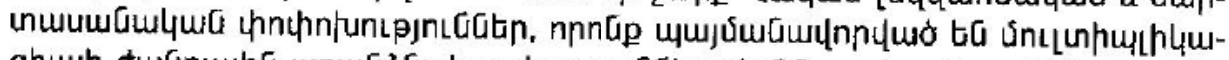

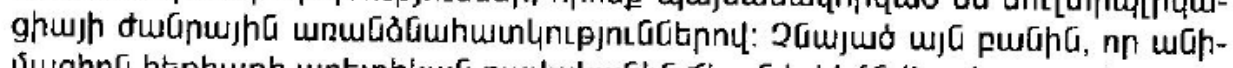

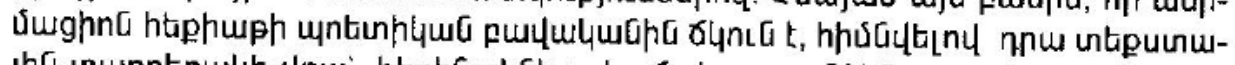

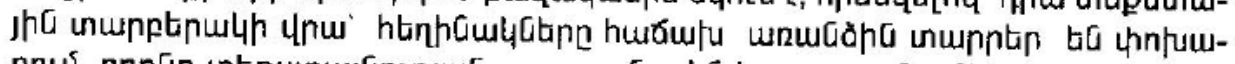

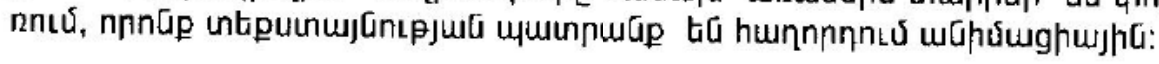

